\title{
THE ROUTE OF INGESTED EGG WHITE TO THE SYSTEMIC CIRCULATION
}

\author{
By H. L. ALEXANDER, KATHERINE SHIRLEY AND DUFF ALLEN \\ (From the Department of Internal Medicine, Washington University School of Medicine and \\ Barnes Hospital, St. Louis)
}

(Received for publication October 11, 1935)

There is little doubt that unaltered food proeins may reach the systemic circulation in small amounts. In early experiments, protein substances were injected into ligated intestinal loops, and the nitrogenous material therein was observed to diminish gradually, thus indicating partial absorption through the intestinal wall. Soon after the introduction of the precipitin test for the demonstration of small amounts of protein, the method was applied to the detection of ingested proteins in the blood stream. Uhlenhuth in 1900 (1) was probably the first to use the test for this purpose. After feeding egg white to rabbits for a long time, he found traces in the systemic blood. Ascoli and Vigano (2) and Ganghofner and Langer (3) repeated the experiment a few years later, with different proteins, in dogs. They secured positive precipitin reactions soon after a single feeding. Hamburger and Sperk (4) were doubtful of their results in similar experiments. Schloss and Worthen (5) applied the test to humans and found that the digestive tract of normal infants is usually impermeable to protein food. In nutritional and gastro-intestinal disorders, however, they detected egg protein in the urine. Later, Schloss and his associates $(6,7)$ found that the enteral absorption of antigenic proteins (egg white, milk, sheep serum) by normal or marasmic infants led to the appearance of specific precipitins in the blood, indicating the transfer of small amounts of protein from the gut. Here, the blood acquired the properties of an immune serum, with precipitins appearing in about two weeks. In the earlier tests the systemic blood was mixed with immune rabbit serum containing precipitins. Hektoen, Kanai and Dragstedt (8) fed thyroglobulin to fasting dogs, and found precipitins in the portal and systemic blood but none in the digestive mucosa, indicating, they believed, a direct absorption into the tributaries of the portal vein.
The anaphylactic method has likewise been used to demonstrate that small amounts of protein escaped through the bowel wall. Rosenau and Anderson (9) in 1906 shocked parenterally sensitized guinea pigs by feeding them the specific antigen. Hettwer and Kriz (10) obtained the same results and worked out conditions of the experiment in detail. Van Alstyne $(11,12)$ injected guinea pigs sensitized to egg albumen, horse serum, edestin, and other proteins, with the blood and urinary proteins of dogs fed these substances, and obtained shock.

Walzer (13), by using the Prausnitz-Küstner technic of passive transfer of reagins, more recently introduced a much more delicate method for the detection of minute amounts of specific allergens. Serum from a patient very sensitive to fish was injected intradermally into a normal individual, who on eating fish shortly developed a marked urticarial reaction at the site of injection. Brunner and Walzer (14) believed that the absorption of detectable amounts of fish protein from the gastro-intestinal tract is a normal phenomenon, since they observed it in 93.8 per cent of 65 patients tested. Smyth and Stallings (15) obtained similar results by sensitizing skin sites of newborn babies with reagins to egg, and obtaining local reactions after a colonic flush with 5 per cent egg white in water.

From the foregoing experiments, which have been amply confirmed, it appears beyond question that small amounts of ingested proteins reach the systemic blood. It is surprising how little attention has been given the pathway by which they reach the circulation. There are three possible routes: (1) by absorption through the surfaces of the mouth and esophagus; (2) via the portal vein to the liver with transfer there to the systemic blood; (3) via the lacteals and thoracic duct lymph.

Concerning the first possibility, this probably 
occurs in highly sensitized individuals who within a few minutes after tasting the offending food begin to wheeze or to develop urticaria. Ratner and Gruehl (16) sensitized animals by parenteral injection and shocked them by feeding the specific protein. One animal died within three minutes. By the use of the clotting time, Mills and his coworkers (17) detected tissue fibrinogen in the blood two and one-half minutes after the fibrinogen was ingested. The rapidity of results in such instances strongly indicate direct absorption into the systemic circulation through the capillaries of the upper alimentary tract.

Other than Hektoen's demonstration by precipitin test, of thyroglobulin in the portal circulation after. its ingestion, little work has been done toward detecting food proteins in the portal blood.

The idea that protein foods may enter the lymph of the thoracic duct was first proposed by Ascoli and Vigano (2). They found, however, the unexpected presence of precipitins for dog lymph in rabbit serum, so they could not complete the experiment. Banks (18) recently confirmed this observation, there being but four sera that he could use for the experiment. With these, no egg white was detected in the lymph. Ishikawa (19), likewise, by precipitin tests, failed to detect egg albumen in the thoracic lymph after oral administration, but did find some after it had been injected directly into the intestine. Banks observed no ingested egg white in the thoracic lymph by the anaphylactic method nor by the passive transfer method. Concerning the latter test, Banks speaks of using the method of Coca and Grove, a modification of the Prausnitz-Küstner technic, for the detection of atopic reagins. Instead of using human serum containing reagins, transferred to human skin (the method of Coca and Grove), he employed an anti-egg-rabbit serum injected intracutaneously into rabbits. The distinction between the two tests is important since the Prausnitz-Küstner technic is so much more delicate than any other that it should be the method of choice. Injection of anti-egg-rabbit serum into the skin of rabbits results in a totally different immunologic process.

In view of the fact that the passive transfer of reagins has not been applied to the portal blood or thoracic lymph for the detection of ingested protein, this test was used in the following experiments, and compared to the precipitin method.

\section{EXPERIMENTAL}

\section{Precipitin tests}

Anti-egg-rabbit serum was prepared by injecting a rabbit, weighing 3 kilos, intravenously three times with $4 \mathrm{cc}$. of $1: 10$ dilution of sterile eggwhite in distilled water at 4 day intervals. Nine days after the last injection the animal was bled under sterile precautions. The separated serum diluted 1:5 had a precipitin titer of $1: 40,000$. The ring test was used by layering the material to be examined over the immune rabbit serum in tubes $8 \mathrm{~mm}$. by $75 \mathrm{~mm}$. Readings were made after standing in a water bath at $37.5^{\circ} \mathrm{C}$. for 1 hour. Control tests with normal rabbit serum were made.

\section{Prausnitz-Küstner test}

Human serum containing reagins to egg in a titer of $1: 1,000,000^{1}$ was secured. One-tenth of a cubic centimeter was injected intradermally at several sites in the skin of normal individuals. A negative preliminary skin reaction to egg white was first secured, and the subject was given an egg-free diet previous to the test. Two-hundredths of a cubic centimeter of the material to be tested was injected intradermally at the sites of reagin introduction, 24 hours later. The bleb raised by the testing material was outlined in India ink, and the resulting wheal of a positive reaction was also outlined 15 minutes later. These ink marks were traced through thin paper. The circumference of each mark was measured with a planimeter and the difference between the two readings recorded in square centimeters. This result represented the size of the skin reaction in two dimensions.

Dogs weighing about 10 kilos were fasted for 24 hours and then given egg white in the amounts of $1 \mathrm{egg}$ for every 2 kilos of body weight, by stomach tube. Several dogs ate the egg white from a pan, and no tube was introduced. Three hours later (occasionally 2 hours) the animal was anesthetized with ether. Lung sufflation under posi-

1 This serum was kindly furnished by Dr. H. Donnally of Washington, D. C. 
tive pressure through a tracheal cannula was begun. Lymph was aspirated from the thoracic duct which was isolated just above the diaphragm; the abdomen was opened and blood taken from the portal vein; and the aorta was aspirated for systemic blood. Attempts to secure lymph periodically from the thoracic duct in the neck were unsuccessful because of clotting.

Sera from the portal vein and aorta were separated from the clot, and these and the lymph were put through Zeitz filters to insure sterility. Each was used as test material.

\section{RESULTS}

Although no precipitins for dog lymph appeared in the rabbit serum used, the lymph was occasionally cloudy despite preliminary fasting. In such instances, the test was unreadable. Results in 9 dogs are recorded in Table I. As controls, tests were done for precipitins to egg white in 5 dogs fed raw beef. All of these were negative.
Egg white was present in varying amounts in the lymph of the thoracic duct and in the systemic blood. This is in contrast to the consistently negative results with portal blood.

TABLE II

Passive transfer tests for egg white (wheal formation recorded in square centimeters)

\begin{tabular}{|c|c|c|c|c|c|c|c|c|}
\hline \multirow{2}{*}{$\underset{\text { number }}{\text { Dog }}$} & \multicolumn{4}{|c|}{ Tests } & \multicolumn{4}{|c|}{ Controls } \\
\hline & Lymph & $\begin{array}{l}\text { Sys- } \\
\text { temic }\end{array}$ & $\begin{array}{c}\text { Por- } \\
\text { tal }\end{array}$ & $\begin{array}{c}\text { Egg } \\
1: 1000\end{array}$ & Lymph & $\begin{array}{l}\text { Sys- } \\
\text { temic }\end{array}$ & $\begin{array}{c}\text { Por- } \\
\text { tal }\end{array}$ & $\begin{array}{c}\text { Egg } \\
1: 1000\end{array}$ \\
\hline $\begin{array}{r}1 \\
2 \\
3 \\
4 \\
5 \\
6 \\
7 \\
8 \\
9 \\
10\end{array}$ & $\begin{array}{c}\text { sq.cm. } \\
1.25 \\
1.62 \\
.68 \\
1.25 \\
1.56 \\
1.50 \\
1.00 \\
1.06 \\
.68 \\
1.12\end{array}$ & $\begin{array}{r}\text { sq.cm. } \\
1.06 \\
1.31 \\
.62 \\
1.18 \\
.68 \\
1.37 \\
1.00 \\
1.12 \\
.50 \\
.62\end{array}$ & $\begin{array}{r}\text { sq.cm. } \\
1.00 \\
1.00 \\
.50 \\
.56 \\
1.00 \\
.56 \\
.56 \\
.81 \\
.43 \\
1.06\end{array}$ & $\begin{array}{c}\text { sq.cm. } \\
1.81 \\
1.00 \\
.62 \\
1.81 \\
1.62 \\
1.18 \\
1.56 \\
1.50 \\
1.25 \\
1.62\end{array}$ & $\begin{array}{r}\text { sq.cm. } \\
.68 \\
1.06 \\
.43 \\
.50 \\
.37 \\
.37 \\
.25 \\
.68 \\
.50 \\
.62\end{array}$ & $\begin{array}{r}\text { sq.cm. } \\
.62 \\
.87 \\
.31 \\
.93 \\
.56 \\
.25 \\
.75 \\
1.25 \\
.62 \\
.50\end{array}$ & $\begin{array}{r}s q . c m . \\
.87 \\
1.18 \\
.62 \\
.62 \\
.50 \\
.50 \\
.75 \\
.68 \\
.56 \\
.93\end{array}$ & $\begin{array}{r}s q . c m . \\
.18 \\
.25 \\
.12 \\
.12 \\
.31 \\
.18 \\
.25 \\
.18 \\
.18 \\
.25\end{array}$ \\
\hline verage & 1.18 & 0.95 & 0.75 & 1.38 & 0.55 & 0.66 & 0.72 & 0.21 \\
\hline
\end{tabular}
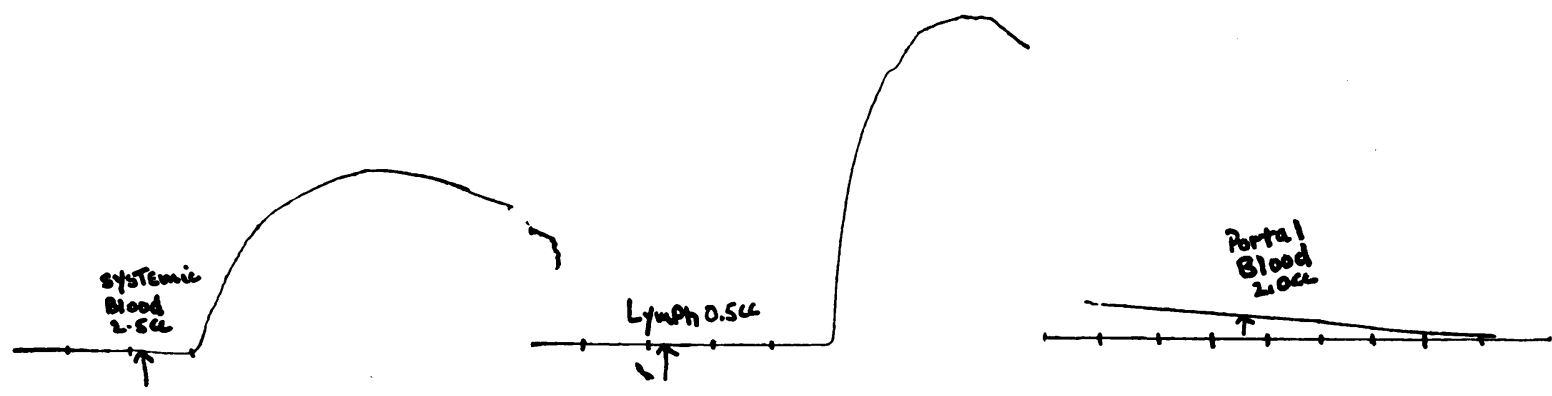

Fig. 1. Reactions of Uterine Horns of Guinea Pigs Sensitized to Egg White, Suspended in a Bath of Tyrode's Solution.

TABLE I

Precipitin tests for egg white with lymph, systemic blood and portal blood

\begin{tabular}{|c|c|c|c|c|c|c|}
\hline \multirow{2}{*}{$\underset{\text { number }}{\text { Dog }}$} & \multicolumn{3}{|c|}{ Anti-egg-rabbit serum * } & \multicolumn{3}{|c|}{ Normal rabbit serum * } \\
\hline & Lymph & Systemic & Portal & Lymph & Systemic & Portal \\
\hline $\begin{array}{l}1 \\
2 \\
3 \\
4 \\
5 \\
6 \\
7 \\
8 \\
9\end{array}$ & $\begin{array}{c}++++ \\
\mathbf{C}+ \\
\mathbf{C} \\
0 \\
++++ \\
\mathbf{C} \\
++++ \\
++++\end{array}$ & $\begin{array}{c}+ \\
++++ \\
++++ \\
0 \\
0 \\
+ \\
+ \\
+ \\
0\end{array}$ & $\begin{array}{l}0 \\
0 \\
0 \\
0 \\
0 \\
0 \\
0 \\
0 \\
0\end{array}$ & $\begin{array}{l}0 \\
0 \\
0 \\
0 \\
0 \\
0 \\
0 \\
0 \\
0\end{array}$ & $\begin{array}{l}0 \\
0 \\
0 \\
0 \\
0 \\
0 \\
0 \\
0 \\
0\end{array}$ & $\begin{array}{l}0 \\
0 \\
0 \\
0 \\
0 \\
0 \\
0 \\
0\end{array}$ \\
\hline
\end{tabular}

* Dilution of serum was $1: 5$.

$+\mathrm{C}=$ Cloudy.
In a few instances anaphylactic tests were carried out with the Dale technic (20). Uterine horns from guinea pigs sensitized to egg white two to three weeks previously were suspended in oxygenated Tyrode's solution and the test material added to the bath. Difficulty was encountered in securing muscle strips sufficiently sensitive on the date of operation to contract with weak dilutions of egg white. However, on a few occasions the results were satisfactory, as recorded in Figure 1. Here again, egg white appeared in the thoracic duct lymph and systemic blood but none in the portal blood.

The results of passive transfer are recorded in Table II.

The relatively large size of the control wheals 
from systemic and portal blood may be explained as irritative reactions. There has been some recorded experience with the effect of injections of various animal sera into human skin. The incidence of immediate wheal formation appeared to vary according to the species of serum introduced. With rabbit serum, injected intradermally, positive reactions were rare (21); with horse serum they varied from 6 per cent to 27 per. cent in several reported series (22); with guinea pig serum, immediate reactions were almost constant (23). No recorded experience with the injection of dog serum into human skin could be found other than the single case of Simon (24), which reacted positively to most of the mammalian sera tried. It would appear, therefore, that dog serum like guinea pig serum gives a positive wheal when injected into human skin. In the portal blood there evidently is an added irritative factor. Although there has been no report heretofore of the effect of injection of dog lymph into human skin, it ap-

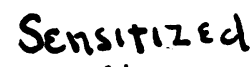

Sites

$\underset{\substack{\text { Systemie } \\ \text { Blood }}}{1.06}$

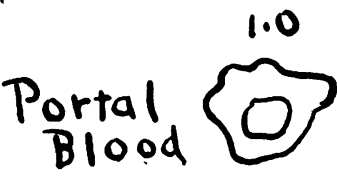

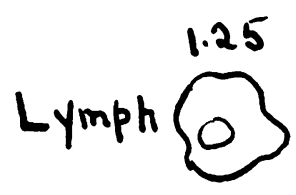

Controls
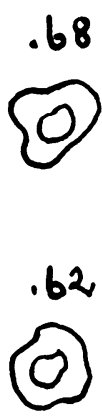

.87

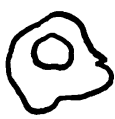

1.8

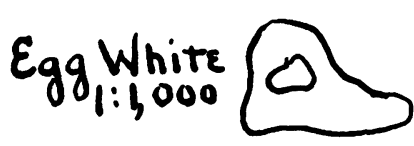

Fig. 2. Dog Number 1. Wheal Formation at the Sites of Passive Transfer to Normal Human Skin of Reagins to EgG. parently behaves similarly to the sera of systemic blood (Figure 2).

\section{DISCUSSION}

The small amount of published data concerning the pathway by which traces of ingested proteins reach the systemic blood are at variance with the data here presented. We did not experience any difficulty with a non-specific reaction as reported by several observers in performing precipitin tests with dog lymph in immune rabbit serum. The positive results that we obtained are in contrast to the negative findings of Banks (18), who recorded the four tests he was able to perform, as negative. They likewise differ from the observations of Ishikawa and of Matsui and Ida, whom he quotes. The difficulty that we encountered was the frequent appearance of turbid lymph despite the fact that the dogs had been fasting. Four of the five positive reactions, however, gave a heavy thick ring and precipitate. The test was negative but once.

Hektoen, Kanai and Dragstedt (8) reported precipitin reactions in the portal blood serum to ingested beef thyroglobulin, but none to beef muscle. Egg white apparently behaves differently, since in no instance either by precipitin test or by passive transfer was it detected in the portal circulation. One would expect to find traces of it there when egg white was present in large amounts in the systemic blood which is pumped into the superior mesenteric artery. No explanation of its absence is offered. Although portal blood itself caused an irritative reaction, with the passive transfer method, the fact that the average size of the control wheals was larger than that of the test material makes it quite unlikely that the portal blood contained egg protein.

It appears that under the conditions of the above experiments ingested egg white reaches the systemic circulation via the thoracic duct lymph quite consistently. This is of interest since the egg white was introduced into a fasting stomach and therefore was probably not carried through the lacteals with fat in the food.

According to Mann (25), egg white passes through the stomach of dogs rapidly. This could account for the results obtained, since some of it may have entered the intestines undigested. The fact remains that other proteins introduced 
by stomach tube have been found repeatedly in the systemic blood, and they must also have passed through the gut wall but little changed. Ether anesthesia likewise may have influenced the experiment. This possibility was not checked, although since each dog was sacrificed, the animal was under ether but a short time.

\section{CONCLUSIONS}

1. Egg white fed to dogs by stomach tube was detected in the systemic circulation by precipitin tests by the Prausnitz-Küstner technic of passive transfer, and occasionally by anaphylactic tests (Dale reaction).

2. When these tests were applied to lymph from the thoracic duct, the presence of egg white was readily demonstrated. By the same technic, no egg white appeared in the portal blood.

3. Under the conditions of the experiment, it appears that the route of ingested protein to the systemic circulation is via the thoracic duct lymph.

\section{BIBLIOGRAPHY}

1. Uhlenhuth, Neuer Beitrag zum spezifischen Nachweis von Eiereiweiss auf biologischem Wege. Deutsche med. Wchnschr., 1900, 26, 734.

2. Ascoli, M., and Viganò, L., Zur Kenntniss der Resorption der Eiweisskörper. Ztschr. f. physiol. Chem., 1903, 39, 283.

3. Ganghofner and Langer, J., Utber die Resorption genuiner Eiweisskörper im Magendarmkanal neugeborener Tiere und Saüglinge. München. med. Wchnschr., 1904, 51, 1497.

4. Hamburger, F., and Sperk, B., Biologische Untersuchungen über Eiweissresorption vom Darm aus. Wien. klin. Wchnschr., 1904, 17, 641.

5. Schloss, O. M., and Worthen, T. W., The permeability of the gastroenteric tract of infants to undigested protein. Am. J. Dis. Child., 1916, 11, 342.

6. DuBois, R. O., Schloss, O. M., and Anderson, A. F., The development of cutaneous hypersensitiveness following the intestinal absorption of antigenic protein. Proc. Soc. Exper. Biol. and Med., 1925, 23, 176.

7. Anderson, A. F., Schloss, O. M., and Myers, C., The intestinal absorption of antigenic protein by normal infants. Proc. Soc. Exper. Biol. and Med., 1925, 23, 180.

8. Hektoen, L., Kanai, P. H., and Dragstedt, L. R., A study of protein absorption from the digestive tract by the precipitin test with special reference to thyroglobulin. J. A. M. A., 1925, 84, 114.

9. Rosenau, M. J., and Anderson, J. F., A study of the cause of sudden death following the injection of horse serum. Hygienic Lab. Bull., U. S. Pub. Health Service, 1906, 29, 67.

10. Hettwer, J. P., and Kriz, R. A., Absorption of undigested protein from the alimentary tract as determined by the direct anaphylaxis test. Am. J. Physiol., 1925, 73, 539.

11. Van Alstyne, E. V. N., and Grant, P. A., The absorption of albumin without digestion. J. Med. Research, 1911, 25, 399.

12. Van Alstyne, E. V. N., The absorption of protein without digestion. Arch. Int. Med., 1913, 12, 372.

13. Walzer, M., Studies in absorption of undigested proteins in human beings. I. A simple direct method of studying absorption of undigested protein. J. Immunol., 1927, 14, 143.

14. Brunner, M., and Walzer, M., Absorption of undigested proteins in human beings. Arch. Int. Med., 1928, 42, 172.

15. Smyth, F. C., and Stallings, M., Studies in passive tranfer. IV. Rectal absorption of the antigen (egg white). J. Allergy, 1931, 3, 16.

16. Ratner, B., and Gruehl, H. L., Passage of native proteins through the normal gastro-intestinal wall. J. Clin. Invest., 1934, 13, 517.

17. Mills, C. A., Dorst, S. E., Mynchenberg, G., and Nakayama, J., Absorption from the intestine and excretion through the kidney of an unaltered complex protein substance, tissue fibrinogen. Am. J. Physiol., 1922, 63, 484.

18. Banks, B. M., Concerning the absorption of unsplit protein through the lacteals. Proc. Soc. Exper. Biol. and Med., 1933, 31, 51.

19. Ishikawa, I., Experimentelle Studie über die Permeabilität des Darmkanals für heterologes Eiweiss. Jap. J. M. Sc. Tr., IV. Pharmacol., 1928, 2, 205.

20. Dale, H. H., The effect of varying tonicity on the anaphylactic and other reactions of plain muscle. J. Pharmacol. and Exper. Therap., 1913, 4, 517.

21. Jones, T. D., and Mote, J. R., The phases of foreign protein sensitization in human beings. New England J. Med., 1934, 210, 120.

22. Tuft, L., Serum sensitiveness after toxin-antitoxin. A clinical and laboratory study. J. Allergy, 1932, 3, 235.

23. Simon, F. A., and Rackemann, F. M., The development of hypersensitiveness in man. I. Following intradermal injection of the antigen. J. Allergy, 1934, 5, 439.

24. Simon, F. A., A species nonspecific antigenic factor in mammalian serums. J. Allergy, 1934, 6, 1.

25. Mann F., Personal communication. 